Pecvnia, 3 (2006), pp. 163-187

\title{
Russian Financial Sector: Adjustment and Management
}

\author{
Vitaly J. Ozira
}

El presente artículo examina problemas generales concernientes al sector financiero de Rusia a la luz del sistema económico apoyado en los mecanismos de mercado de la distribución de los recursos. Después de la introducción que describe las funciones de dicho sector en las condiciones de mercado, el artículo representa un cuadro típico de problemas que frenan el funcionamiento eficaz del sistema financiero como instrumento de desarrollo. Asimismo el autor ofrece recomendaciones prácticas basadas en el resultado del análisis llevado a cabo por él. El texto del artículo contiene los principios fundamentales que son, propiamente dicho, los marcos conceptuales del presente trabajo.

Las finanzas, como es sabido, están estrechamente vinculadas a las peculiaridades jurídicas, políticas y culturales de una sociedad concreta. Los recursos financieros son una institución llamada a garantizar la interacción de los diferentes grupos dentro de la sociedad. De ahí que fuera de su función principal -la de la contabilidad pública- las demás funciones del
This paper reviews general issues related to Russian financial system and policies in the context of economies relying to a significant extent on market mechanisms to allocate resources. After a brief introduction describing the functions of the financial sector in a market economy, the paper presents an inventory of the most common problems hindering the effective performance of the financial systems as a development tool, and some policy guidelines based on the analysis. The text aims at presenting a brief exposition of the basic principles that provide a conceptual framework to review the issues.

Finance, like money, is not a reality which exists independently from the specific cultural, political and legal features of a given society. The reason is that finance is an institution, which organizes relevant modes of interaction among various groups or individuals within that society. Therefore, beyond its most basic function (providing the "social accounting" framework needed to keep track of various 
sector financiero no deben ser necesariamente universales.

Los criterios expuestos en el articulo reflejan la opinión del autor, por ende no pueden ser interpretados como un documento oficial acerca de cómo funciona el sector financiero y su gestión.

Palabras clave: Movilización de recursos; asignación de recursos; factores sociológicos; activos intangibles. economic units claims on the social resources), the functions fulfilled by the financial sector need not be the universal.

The views expressed in the paper are the author's own responsibility and should not be interpreted as presenting the official position paper on financial sector management.

Key words: Resource Mobilization; Resource allocation; Sociological factors; Intangible assets.

\section{RUSSIAN FINANCIAL SYSTEM AND DEVELOPMENT}

\section{Introduction}

Over the last two decades, the perception of the importance of the financial sector (the commercial banks, insurance companies, development financial companies, securities markets, etc.) to development has changed substantially. Twenty years ago financial systems in our country were viewed primarily as tools of government in the development process, namely, institutions which could, on the one hand, be tapped for funds to finance government and public enterprise expenditures and, on the other, be used to direct credit to what were considered the priority sectors. Today the approach has changed. Financial systems are viewed as important in their own right as providers of key services such as: the mobilization of resources; allocation of credit; pooling, pricing and trading of risk; and monitoring and supervising borrowers behaviour.

Emphasis on the private sector. In the 1960/70s and 1980s, the government was seen as the engine of economic growth; today much greater emphasis is being placed on the role of the private sector. This is true both in the postsocialist world and in the countries with more mixed economies. The financial system is clearly important to the success of the private sector. For example, while governments can raise funds through taxation, the private sector must use the financial system to raise the resources, which cannot be generated through retained earnings.

In a market economy, the financial sector fulfils normally two functions relevant to the long run performance of the economy. First, the financial sector fosters the mobilization of resources for capital accumulation. Second, the financial sector determines the allocation of the resources it mobilizes among various alternative investment opportunities. 


\section{Resource Mobilization}

The mechanisms by which the financial sector mobilizes resources for capital accumulation are usually described in terms of intermediation between the economic agents in surplus, who accumulate financial assets, and the economic agents in deficit, who typically "borrow" the resources made available to them to acquire productive capital. The argument goes as follows: By making available financial assets featuring characteristics more desirable, from the savers' point of view, than the characteristics of assets that the borrowers could offer on their own, the financial sector induce savers to save more and, therefore, to make more resources available for the financing of investment. It is important to remember that the success of the financial sector in raising funds to be intermediated depends on its ability and willingness to offer the public a great variety of assets corresponding to the various needs and preferences of economic agents: Thus the financial sector ought to satisfy demands as diverse as the demand for the medium of exchange (money), the demand for earning assets exhibiting various combinations of risk, return and liquidity (all kinds of bonds and shares), the demand for security in old age (pension systems) and the demand for assistance in case of loss of human capital (life and disability insurance policies).

The essential contribution of the financial sector, in this story, is its ability to transform the characteristics of assets issued by borrowers to meet the circumstances of potential lenders. The most obvious transformations usually performed at the intervention of the financial sector are increased liquidity (through either increased marketability or maturity transformation), risk reduction (through increased liquidity, economics of scale in portfolio diversification and professional specialization in risk assessment) and enhanced divisibility (sometimes called denomination transformation).

In addition to mobilizing resources through activities of intermediation between lenders and borrowers, the financial sector (which includes, in all contemporary economies, the monetary sector) also mobilizes resources for capital formation by making available to the public convenient temporary abodes of purchasing power (in the form of money or other liquid assets) which facilitate the accumulation of wealth progressively through time until the accumulated savings are sufficient to allow the purchase of a "bulky" real asset (a new equipment, which Russia in need...). 
Although this mechanism is redundant in economies where credit markets are fully developed, it is likely to be important in the countries like Russia where capital markets are fragmented and where significant numbers of people or enterprises do not have easy access to all the services of the "organized" financial sector, as explained by Ronald McKinnon in his classical book Money and Capital in Economic Development (Brookings Institution, Washington, D.C. 1973).

\section{Resource Allocation}

In the broadest sense, the financial sector's function of resource mobilization is already dealing with an issue of resource allocation: mobilizing resources for investment implies inducing economic agents to allocate resources to wealth accumulation rather than to consumption or leisure. However, in this section, we will focus more narrowly on the mechanisms by which the financial sector allocates saving among different investment opportunities.

The financial sector plays an important role in allocating saving among alternative investment projects through two different channels. First, and most obviously, financial intermediaries directly allocate the resources they have raised among the many borrowers applying for funds. Second, they influence the behaviour of savers who can use their funds either to acquire a productive asset or to acquire financial assets issued by the financial sector. The choice of the savers will be determined by a comparison of the relative characteristics of risk and return of the investment project they are considering with those of the available financial assets. Savers will make their resources available to the financial sector, for allocation to other investors, rather than purchasing real assets themselves, only if the risks and returns on financial assets issued by the financial intermediaries compare favourably with these of a real asset.

\section{PROBLEMS RESULTING FROM FACTORS SPECIFIC TO THE} FINANCIAL SECTOR

For the Russian financial system to fulfil its functions of resources mobilization and resources allocation efficiently, certain conditions must be met. These conditions relate to the interest rates charged the borrowers, the interest rates paid to the depositors (or, in 
general, the yield of financial assets for savers) and the possible wedge between these two type of rates.

A variety of factors specific to the financial sector may hinder either the development or the smooth functioning of the financial system and prevent it from fulfilling its functions. For the sake of expository convenience, these factors can be regrouped into institutional weaknesses, infrastructure weaknesses, manpower weaknesses and sociological factors.

\section{Institutional weaknesses}

Under this heading, we will discuss the effect of rules and regulations designed to improve the functioning of the financial sector (as opposed to the rules and regulations which have other goals, such as the effectiveness of monetary policy or the collection of fiscal revenue). These rules deal usually with entry in the industry and with supervisory and prudential regulation.

Supervisory and prudential regulation, particularly for the banking system, is justified by the fact that the funds at risk in the industry exceed by far the stake of the owners and of the managers of the financial intermediaries. Prudential regulation typically involves setting some minimum capital requirements, defining limits on certain types of investments, prohibiting certain business relationships (like self-dealing) and requiring the publication of relevant information, like regular financial statements.

Problems arise either when the regulations are ineffective (because, for example, they presuppose a level of expertise which is not available; or because they ignore important sociological, political or legal factors or well entrenched business practices), or when they are effective but ill-designed. When supervisory and prudential regulation is ineffective (or nonexistent), the danger is that financial intermediaries will undertake too much risk, that their portfolios will deteriorate when the circumstances become adverse and that in the longer run a significant part of the financial sector will suffer financial distress.

When prudential regulation is effective but ill-designed, it may prevent the financial sector to perform at its best and, in particular, to handle risk in an efficient way. A common weakness is that, often, prudential regulation focuses unduly on specific subsets of the balance sheet of the financial intermediaries and, in so doing, fails to take into 
account the interdependence of assets and liabilities as well as the role of portfolio diversification in assessing risk: By constraining too rigidly the composition of the balance sheet, prudential regulation may prevent financial managers to take fully advantage of portfolio diversification or of other techniques to reduce overall risk. The prohibition against the holding of foreign assets and the narrow specialization of certain institutions in terms of sectors or maturity ranges are also examples of regulatory constraints which may result in unnecessary risks for the financial sector, and may be one of the sources of financial distress in the long run.

Regulation of entry into the financial industry in Russia is sometimes a mere component of prudential regulation: This is the case, for example, for rules setting minimum capital requirements or ownership disclosure and restrictions as conditions to obtain a licence to operate as a financial intermediary. However, regulation of entry is also aimed at organizing competition. If the effect of regulation is to foster sustainable competition, by allowing the entry of innovative or cost-effective firms (and the exit of inefficient ones), or by preventing the monopolization or cartelization of the financial sector, entry regulation contributes to the efficiency of the financial system in normal circumstances.

The main exception to the desirability of competition is related to the case where financial distress is prevalent throughout the system.

The real danger of entry regulation is that ill-designed rules may (1) undermine competition and (2) induce some financial intermediaries to specialize excessively in a segment of the market.

Restricted entry, including in some cases discrimination against foreign financial intermediaries, can be expected to weaken competition. Undermining competition might increase the profitability of the financial intermediaries, but at the expense of the development and deepening of the financial sector. By increasing the wedge between interest rates charged to borrowers and interest rates paid to creditors, the absence of competition within the financial sector leads to disintermediation and to fragmentation of the financial markets: Resources available for investment do not systematically flow to their most efficient allocation any more.

Some low yield investments may be undertaken whereas some higher yielding projects may be abandoned, because the interest 
rates are distorted by market power and do not reflect the expected yield of real assets (adjusted for risk) and the cost of intermediation.

Another aspect of entry regulation is that, by reserving certain types of activities to specific institutions, it may give an incentive to some financial intermediaries to specialize excessively in these protected activities. In addition to the usual effects of lack of competition, a consequence of this specialization may be an insufficiently diversified portfolio and an unnecessary level of risk which, in adverse circumstances, may result in financial distress.

\section{Infrastructure weaknesses}

To fulfil its functions effectively, the financial sector requires the availability of a basic infrastructure. For example, the integration of financial markets will be hindered if there are no adequate communication facilities making possible a rapid transfer of funds and information. Less obvious than the need for a physical infrastructure like a communication network, but equally important, there must be a social infrastructure in the form of supporting professions (accounting profession, legal profession, auditing profession) and institutions (well defined property rights, mechanisms to handle conflicts and to enforce contracts, a stable monetary unit) necessary to the operation of a large scale financial sector. Indeed, the size of the financial sector and therefore its ability to integrate financial markets depends on mechanisms to generate a reasonable degree of trust and confidence in the system. If there are no accountants and auditors to guarantee the availability of reliable information on the financial viability of enterprises and financial intermediaries, and no reliable judges, policemen or other agents of social control to guarantee that contracts will be enforced if needed, the necessary trust and confidence which is the foundation of financial intermediation will have to rest on personal relationships.

A system based on personal relationships is indeed the original form of the banking system in the pro-industrial era and this model is still prevalent in the informal sector of Russia. However, as long as the economy must rely on a financial system founded mainly on personal relationships, the financial markets are likely to remain fragmented. 


\section{Manpower weaknesses}

Finance, like other industries, requires the availability of trained manpower having the expertise and the know-how to manage the enterprise, market its products and execute the different tasks involved in the production of the output. The lack of manpower can create a bottleneck resulting in a scarcity of financial services, higher costs of financial intermediation, and, therefore, a less efficient mechanism of resources mobilization and saving allocation that would be possible otherwise.

A manpower constraint may be alleviated by the importation of financial expertise or of financial services. However, the immediate effectiveness of this alternative is likely to be constrained by the importance of a good understanding of the local environment (including its cultural and legal institutions) for a sound assessment of financial risks and opportunities. As reliance on imported financial services may be feasible in some sectors (say, the trade oriented manufacturing sector) but not in others (say, rural enterprises), a possible outcome is increased market segmentation and inefficient allocation of saving.

\section{Sociological factors}

The dependence of the financial sector upon a host of cultural, legal and political factors has already been emphasized. These "sociological" factors may sometimes hinder the development of the financial sector, and sometimes be responsible for its vulnerability when crises emerge.

For example, in 1988 the Harvard Business School, in conjunction with the Soviet Union's Institute of External Economic Affairs (IEEA), began a study of managerial decision making at U.S. and Soviet plants in order to lay groundwork for future joint-venture operations between the two countries. «Behind the Factory Walls: Decision Making in Soviet and U.S. Enterprises», this book published in both countries, documents the findings of this unique collaborative effort, itself a joint venture project.

A binational team of two Soviet and two American researchers (the author was one of them) spent several months at comparable U.S. and Soviet plants involved in the manufacture of engines and electrical equipment. Enjoying unprecedented access to personnel and 
documents, the team concentrated on four decision issues: the formation and implementation of an annual business plan. the hiring and firing of managers, the acquisition of capital equipment, and the introduction of new products. A number of areas - finance, human resources. and marketing, for example - thus came under the researchers' scrutiny in their exploration of both completed and ongoing decision making inside these enterprises.

The book begins with an examination of some of the fundamental differences in the way Soviets and Americans view life and society. Socialist theory has traditionally held that centralized state planning ownership, and distribution of asset; and rewards is the most rational way to deal efficiently with society's needs and priorities. By contrast, the authors 'note. U.S. theory holds that transactions between organizations and individuals will best reflect and answer society s needs for goods and services. Soviet theory assumes that people can be motivated to work through a sense of collective good and benefit for all. while U.S. theory holds that individuals are best motivated when rewarded directly for their effort.

Not surprisingly, these differing attitudes can be traced in large measure to the disparate histories and evolving cultures of each country.

Note that interlocking can be the expression of fundamental social realities, such as the class structure of the country, but it can also be simply the outcome of a rational mechanism by which markets circumvent certain forms of government interference, such as interest rate ceilings: Channelling credit to a company of the same group is a way for the banks' owners to capture the rent implicit in credit at below market rates.

In case of insolvency of the borrowers, the risk is great that the banks will then engage in "evergreening," by providing the borrowers in distress with the cash flow needed to service their debt. The result is that resources are diverted from creditworthy borrowers to bankrupt borrowers and that the balance sheet of the financial intermediary deteriorates. If widespread, this phenomenon can be responsible for large scale financial distress. The problem discussed in this paragraph illustrates the difficulties which can arise when the formal legal or institutional framework on which the financial sector is organized is not consistent with the various values and practices deeply rooted in the local culture. 


\section{FINANCIAL SECTOR AND THE GOVERNMENT}

The government is involved in financial transactions, either as a result of deficit spending or, occasionally, as a result of the accumulation of financial surpluses, like now the case in Russia. However, the financial activities of the government deserve special attention, for two reasons. First, the potential scale of government transactions is bound to have a significant effect on the financial markets and on the interest rates. Second, because of its authority and its power to shape laws and institutions, the government can devise mechanisms or impose rules to tap the resources of the financial sector, in a way which can affect the ability of the sector to perform its economic functions of resources mobilization and resources allocation.

\section{Administered Interest Rates}

In addition to its indirect influence on interest rates resulting from its transactions on the financial markets, the government may decide to set the interest rates by administrative fiat. There may be many different reasons for this practice. First, if effective, the interest rate ceiling leads to a fragmentation of the financial markets and to a dispersion of the rates of return of investments in real assets: Available real resources are not allocated efficiently. This problem is of course amplified if, rather than one ceiling, there is a multiplicity of ceilings for interest rates applicable to different types of transactions. Second, to the extent that the returns on financial assets available to savers are lower than they would be under market clearing conditions, financial disintermediation occurs and there is a weakening of the function of resources mobilization by the financial sector. Third, as financial intermediaries or their owners attempt to retain for themselves the implicit rent resulting from cheap credit, arrangements emerge by which financial institutions and their borrowers tend to be controlled by the same owners, with the results that the portfolios may become less diversified and more risky than when arm's-length relationships prevail between lenders and borrowers. In addition, this tendency for financial intermediaries and several borrowers to conglomerate into a unified interest group will undermine competition even on markets other than the financial markets, further weakening the process of resources allocation throughout the economy. 


\section{Directed Credit}

The main effect of directed credit is to fragment the financial markets and increase the dispersion of the rates of return of real investment, if the minimum quotas to be lent to privileged sectors can be filled only at a lower rate of interest than that charged on other loans. This outcome represents an inefficient allocation of resources, except if the differences in private rates of return correspond to differences between private and social rates of return due to externalities. Even in that case, the shortfall in income for the financial intermediaries constrained to grant credit at lower interest according to the quotas will reduce their ability to remunerate depositors. If the shortfall is significant, this mechanism would tend to lead to disintermediation and further fragmentation of the financial markets. The financial sector will be hindered in both its functions of resources mobilization and allocation.

\section{Inflation}

In relation to the functioning of financial markets, the topic of inflation is relevant at three levels. First, the very existence of inflation, when combined either with uncertainty regarding the future course of inflation or with nominal rigidities appropriate only in the context of price stability, may create distorted incentives, increased cost of intermediation (and therefore disintermediation) and technical difficulties in handling certain types of risks. Second, stabilization policies aiming at defeating inflation may have important effects on interest rates and exchange rates, on the financial position of the borrowers and therefore on the quality of the balance sheet of financial intermediaries. Third, the desirability to prevent inflation has also important implications concerning the need to develop money and capital markets beyond the banking system.

Inflation in Russia may impose costs on the financial system because of the uncertainty about future inflation or because of surprises about the current inflation. Unexpected inflation has a distributive effect when economic agents are locked into nominal contracts. Thus unexpected inflation redistributes wealth from creditors to debtors. Because some financial intermediaries-the banks-tend in normal circumstances to lend for longer maturities than they borrow, and because nominal interest rates tend to increase with inflation, their financial position suffers when inflation develops as they are not able to adjust the interest charged on their loans as fast as their funding costs. In extreme cases, this 
mechanism could cause insolvency and, of course, disintermediation. More importantly, the very risk of incurring this type of loss should inflation accelerate unexpectedly will provide a strong disincentive to Russian banks to engage into maturity intermediation and will increase the cost of this financial service. Another cause of an increased cost of intermediation will be the attempt by all economic agents to reduce the amount of uncertainty by showing the maturities of nominal contracts: This shortening of maturities will increase the number of transactions and the cost of processing them, which will increase the cost of production of financial intermediaries and hinder an efficient mobilization of resources.

The combination of nominal rigidities and inflation may have very detrimental consequences for the Russian financial system.

\section{Interest rate}

Administrative control over interest rates is sometimes used as a tool of monetary policy, particularly in financial systems where the lack of developed money markets makes it difficult for monetary authorities to influence the interest rate through indirect methods. The problems arising from administrative control over the interest rates are of three kinds. First, if there are many different levels of interest rates, the result will be market fragmentation and an inefficient allocation of resources. Second, to the extent that interest rates are fixed at a lower level than the market-clearing level, they imply credit rationing. Financial intermediaries will have an incentive to recapture part or all of the implicit rent collected by borrowers by making loans to borrowers in which they have some interest: This leads to the creation in Russia of conglomerates of financial and non-financial firms.

The emergence of these conglomerates may result in both a deterioration of the quality of the portfolio of the financial intermediaries and in a breakdown of competition spreading to other markets. Third, by reducing the yield of financial assets available to savers, administrative control of interest rates discourage the accumulation of financial assets and can be a cause of disintermediation. This danger is particularly strong when growing inflation erodes the real rate of return corresponding to any given nominal rate of interest.

Three justifications may be put forward in support of administratively set interest rates. First, as discussed earlier, differences 
between interest rates charged on loans to different sectors may be imposed to reflect externalities. For example, investment in certain sectors may have a social rate of return in excess of its private rate of return, and providing the financing for the project at a lower rate of interest will help ensuring the socially desirable level of investment in that sector. This practice would of course reduce the interest rate that the financial intermediaries forced to grant credit at the privileged rate are able to pay to the depositors, and some disintermediation may result. However, it must be recognized that the usually recommended alternative, which consists of direct subsidies to equalize social and private returns, is also bound to involve some types of distortion as these subsidies have to be financed. The exact type of distortion will depends on the specific mode chosen to finance the subsidies.

The second possible justification for administrative control over interest rates is the lack of competition on financial markets. Administrative controls establishing maxima on interest rates to be charged to borrowers and minima on interest rates paid to depositors are meant to prevent the inefficiencies resulting from the ability of financial intermediaries to use market power. The alternative policy would be to create the conditions for effective competition, for example by opening the domestic market to foreign firms or stimulating innovation on money and capital markets to undermine the market power of existing intermediaries.

The third justification for administratively set ceilings on interest rates is the need to deal with widespread financial distress. As discussed earlier, the combination of distress borrowing by borrowers and "evergreening" lending by financial intermediaries is bound lo create interest rate instability. To prevent the spreading of financial distress to healthy borrowers as a consequence of skyrocketing real rates of interest, administrative control may be necessary, until systemic financial distress is overcome.

\section{Credit Ceilings}

Overall credit ceilings for each bank are sometimes imposed by monetary authorities as a tool to control the aggregate money supply. Although this tool is indeed effective in regulating the money supply, it has the damaging side-effect of destroying competition among the banks, both on the market for loans and on the market for deposits. As a result, 
rates charged on loans tend to be higher and the rates paid to the depositors tend to be low. Disintermediation and fragmentation of the financial markets follow, preventing an efficient mobilization and allocation of resources by the financial system, even if banks are able to prosper.

\section{Required Reserves}

Required reserves are a traditional tool of monetary policy. Establishing a minimum ratio that banks have to maintain between their liabilities and reserves held in cash or in deposit with the central bank enables the central bank to limit indirectly the expansion of the money supply if it is able to control the monetary base.

The main objective of monetary policy is to maintain price stability, by ensuring that the growth rate of the money supply does not exceed the rate of growth of the demand for money. Except by chance, the desirable rate of growth of the money supply according to this criterion will not be identical to the desirable rate of growth of credit, given the propensity to save, the investment opportunities and the borrowing requirements of the government. However, if the organized financial system is limited to a network of banks, the amount of credit which can be granted through the organized sector will be determined by the broad money supply. To break this link between money supply and availability of credit through the organized financial system, it is necessary to develop new types of financial assets, and the markets on which they will be traded. The menu of non-monetary assets is extremely varied and in a fully developed financial system goes from short term Treasury Bills and commercial paper lo bonds and stocks to life insurance policies and pension claims.

\section{THE FINANCIAL SECTOR AND ITS PORTFOLIO}

Circumstances arise when a financial intermediary's borrowers are unable to service their debts out of their income or existing marketable wealth. If the inability of the debtors to service their debts is temporary, they face a mere liquidity problem which can be overcome by further borrowing or an adjustment of the time profile of their debt servicing obligations. However, if the expected future income of the borrowers is insufficient to enable them to repay interest and principal at any time, the problem is a problem of insolvency. In that case, the real value of the 
claims of the financial intermediary on such debtors falls short of their book value. Insolvency of the borrowers implies insolvency of the financial intermediary if its total liabilities exceed the value of its portfolio, i.e. if its own capital falls short of the losses incurred on bad loans. Collapse of the distressed intermediaries could be accompanied by a collapse of the entire system and deprive the economy of even these specific benefits that result from the mere existence of monetary and financial assets and that do not depend on financial intermediation.

\section{Financial Sector and International Markets}

The integration of the domestic economy into world markets can be a source of problems for the financial sector. These potential problems will typically be the result of one of three causes: exchange rate rigidities, changes in trade policy (particularly in the context of an adjustment program) and external shocks.

\section{Exchange Rate Rigidities}

When inflation is higher than abroad, a fixed exchange rate is unsustainable in the long run. However, the timing of the exchange rate adjustment is not known, and adjustment could be delayed for a long time. Three types of problems can arise in this context.

First, some economic agents may speculate against the national currency, by borrowing the domestic currency and converting it into foreign currency, hoping to make a substantial capital gain from the inevitable devaluation. These transactions of course involve a loss of foreign exchange reserve for the Central Bank but can also create problems for commercial financial intermediaries if delays in the adjustment of the exchange rate lead the speculators they financed to bankruptcy. These bankruptcies would be the result of the higher nominal rate of interest payable on domestic currency loans (because of the prevailing inflation and possibly also as a result of the speculative demand for loans in domestic currency) relative to the yield of foreign currency assets. Thus, the quality of the balance sheet of the financial intermediaries will be affected.

Second, some economic actors, either accepting a calculated risk or trusting, out of naivety, the official commitment of authorities to 
maintain the fixed exchange rate, may be encouraged to borrow abroad, in foreign currency, rather than to borrow in domestic currency, in response to the higher nominal rate of interest at home induced by the inflation premium. (This of course tend to increase the reserves of the Central Bank and could enable it to maintain the overvalued exchange rate for longer than would be possible otherwise). When the adjustment Finally comes, these borrowers may become bankrupt and cause a deterioration of the quality of the balance sheet of the domestic financial intermediaries who may have claims on these bankrupt borrowers or on their creditors.

Finally, and more fundamentally, a fixed exchange rate in the context of inflation at home different from that prevailing abroad result in a gradual change in the relative price between goods which are traded on world markets and the so-called "non-tradable goods" which cannot be traded economically on world markets and whose prices are therefore determined by the interaction of local demand and supply. Example of tradable goods are manufactured goods (except in the case of prohibitive protection) and commodities, whereas non-tradable goods include typically construction, electricity and many types of services. As inflation increases in Russia, the relative price of non-tradable goods increases (as the price of tradable goods remained fixed by world markets and the exchange rate). The consequence of this gradual change in relative prices is that entrepreneurs have an incentive to shift their resources from the tradable goods sector to industries producing exclusively for the domestic market Because the misaligned exchange rate is unsustainable, this represent a misallocation of resources.

\section{External Shocks}

Any economy transacting with the rest of the world is likely to be subjected to external shocks in the form changes in the terms of trade. A deterioration of the terms of trade, whatever its specific source (increase in the price of imports, including the price of capital in the form of higher real rates of interest on world markets for capital importing countries, or fall in the price of exports), necessarily reduces the real income of the country. If the reduction of the real income is temporary, it is usually desirable not to adjust the expenditure pattern and to finance the transitory shortfall of income. The difficulty is to establish in practice the distinction between transitory shocks, calling for financing, and permanent shocks, calling for an adjustment of expenditures. 
The eventual inability of a country to service its external debt if it is allowed to finance continuously a shortfall of income over expenditures is probably the most visible aspect of the problem. It is not, however, the most fundamental one, particularly if the external debt is the result of balance of payments support loans.

The fundamental problem is that specific local economic agents who did suffer the loss of real income are attempting to finance the shortfall without cutting expenditures. These agents may be the government, suffering from a reduction in real fiscal revenue; enterprises, suffering from a fall in the price of their output or an increase in the price of their inputs; consumers; or public bodies like "stabilization funds" attempting to stabilize the price paid lo the producers of certain commodities in the face of changes of the price on world markets. To the extent that the domestic financial sector is involved in the financing of an unsustainable pattern of expenditures, the inability of debtors to service their debt is going to affect the quality of their balance sheet. In other words, the result of attempts to finance indefinitely, rather to adjust to, a shortfall in real income due to a deterioration of the terms of trade can result in financial distress within the domestic financial sector. In case of external debt due to balance of payment support borrowing, the inability of a country to service its external debt is likely to reflect a situation of financial distress of its domestic financial system. Thus, to the constraints implied by the lack of access to world financial markets we must add the growing inability of the domestic financial system to mobilize and allocate domestic resources efficiently.

\section{IMPLICATIONS FOR MANAGEMENT}

We have argued at the beginning of this paper that in an economy relying to a significant extent on market mechanisms for its economic management, the financial system has an important contribution to make to the efficient mobilization and allocation of resources to promote capital accumulation and growth. Thus promotion of the development of the financial sector is an appropriate stance of public policy in a growth oriented economy: The financial sector has to be nurtured, supported and its potential for growth harnessed, rather than constrained and discouraged.

This recommendation is simply a specific application to the area of financial sector development of the basic general principle that success of a decentralized system of economic management according to 
market mechanisms requires a positive attitude of the public authorities towards initiatives from the private sector or the decentralized units. As emphasized earlier in the paper, the ability of the financial sector to mobilize resources depends on its ability to offer a variety of instrument corresponding to many different needs of the public (medium of exchange, income-generating assets, pension rights, life insurance policies and other risk-managing devices, etc.), and a successful financial system requires a great deal of flexibility and freedom to allow entrepreneurs in the financial sector to respond to the changing and varied needs of the economic agents.

In a healthy financial system, the main contribution of the authorities is to provide an environment conducive to an efficient functioning of the financial sector. In practice, it means establishing conditions for effective competition on the credit and capital markets, avoiding practices and policies resulting in distorted interest rates and excessive cost of intermediation, and, last but not least, providing the necessary infrastructure (i.e., establishing a stable monetary unit, developing prudential regulations, establishing or strengthening a legal framework for property rights, promoting the development of the supporting professions, etc.).

Although these principles are simple and not particularly controversial, the actual task of managing the financial sector in Russia is nevertheless complex, for two main reasons: First, fostering the efficiency of the financial sector is only one of several goals of the government and potential trade-offs and conflicts may exist among these objectives. Second, the recommendation to foster competition and market-determined interest rates should not be followed blindly because, as we argued earlier, it is appropriate only in a system which is exempt from financial distress.

\section{Restructuring of Insolvent Financial Intermediaries}

The first principle to keep in mind when restructuring insolvent financial institutions is that the losses which are the cause of the insolvency have already been incurred. Adjusting the accounting to reflect these losses is merely the act of recognizing the fact that losses have been incurred, not the source of new losses.

Second, the answer to the question of who should bear the costs resulting from the losses depends on the contractual characteristics 
of the assets and liabilities of the institution. Usually losses are borne by the shareholders through a reduction of their equity in the institution. When the equity is negative, i.e. when the institution is insolvent, some losses are unavoidably incurred by other agents, typically the depositors, a deposit insurance agency or the government.

However, in certain cases, the institution as a going concern may have a positive equity despite the fact that the value of its portfolio of claims on its borrowers falls short of the value of its liabilities to the public. The reason is that the institution may be sufficiently profitable, once recapitalized, to absorb the existing deficit in the longer run. In this case, recapitalization can be implemented through merger with other financial institutions or through the sale of the institution to new investors, at no cost to the government nor to the depositors.

Whether the restructuring of the distressed financial institutions involves liquidation, merger or recapitalization, with or without costs to the government, it is usually important to proceed quickly: Until the capacity of the financial sector to survive in a competitive environment is reestablished, the financial sector will not be able to play its role of promoting the development of the economy to its full potential by an adequate mobilization and allocation of resources.

\section{Management of Bank Intangible Assets}

A real-and revolutionary-opportunity lies in studying and assessing how well prepared a bank's people, systems, and culture are to carry out its strategy.

Measuring the value of such intangible assets is the holy grail of accounting. Employees' skills, IT systems, and organizational cultures are worth far more to many banks than their tangible assets. Unlike financial and physical ones, intangible assets are hard for competitors to imitate, which makes them a powerful source of sustainable competitive advantage. If managers could find a way to estimate the value of their intangible assets, they could measure and manage their company's competitive position much more easily and accurately.

But that's simpler said than done. Unlike financial and physical assets, intangible assets are worth different things to different people. Viewed in this light, it becomes clear that measuring the value of intangible assets is really about estimating how closely aligned those 
assets are to the bank's strategy. If the bank has a sound strategy and if the intangible assets are aligned with that strategy, then the assets will create value for the organization. If the assets are not aligned with the strategy or if the strategy is flawed, then intangible assets will create little value, even if large amounts have been spent on them.

There are three categories of intangible assets essential for implementing any strategy:

- Human Capital: the skills, talent, and knowledge that a company's employees possess.

- Information Capital: the company's databases, information systems, networks, and technology infrastructure.

- Organization Capital: the company's culture, its leadership, how aligned its people are with its strategic goals, and employees' ability to share knowledge.

To link these intangible assets to a company's strategy and performance, Robert S. Kaplan and David P. Norton developed a tool called the "strategy map," which they first introduced in the article for Harvard Business Review, "Having Trouble with Your Strategy? Then Map It" (September-October 2000).

Banks as any company build their strategy maps from the top down, starting with their long-term financial goals and then determining the value proposition that will deliver the revenue growth specified in those goals, identifying the processes most critical to creating and delivering that value proposition, and, finally, determining the human, information, and organization capital the processes require.

The strategic readiness of each type of intangible asset can be thought of as follows:

Human Capital ( $\mathrm{HC})$ : In the case of human capital, strategic readiness is measured by whether employees have the right kind and level of skills to perform the critical internal processes on the strategy map. The first step in estimating $\mathrm{HC}$ readiness is to identify the strategic job families-the positions in which employees with the right skills, talent, and knowledge have the biggest impact on enhancing the organization's critical internal processes. The next step is to pinpoint the set of specific competencies needed to perform each of those strategic jobs. The 
difference between the requirements needed to carry out these jobs effectively and the company's current capabilities represents a "competency gap" that measures the organization's $\mathrm{HC}$ readiness.

Information Capital (IC): The strategic readiness of information capital is a measure of how well the company's strategic IT portfolio of infrastructure and applications supports the critical internal processes. Infrastructure comprises hardware-such as central servers and communication networks-and the managerial expertise-such as standards, disaster planning, and security-required to effectively deliver and use applications. Two categories of applications, in turn, are built on this infrastructure: Transaction-processing applications, such as an ERP system, automate the basic repetitive transactions of the enterprise. Analytic applications promote analysis, interpretation, and sharing of information and knowledge. Either type may or may not be a transformational application-one that changes the prevailing business model of the enterprise. Transformational applications have the most potential impact on strategic objectives and require the greatest degree of organization change to deliver their benefits.

Organization Capital (OC): Organization capital is perhaps the least understood of the intangible assets, and the task of measuring it is correspondingly difficult. Successful banks had a culture in which people were deeply aware of and internalized the mission, vision, and core values needed to execute the company's strategy. These banks strove for excellent leadership at all levels, leadership that could mobilize the organization toward its strategy. They strove for a clear alignment between the organization's strategic objectives and individual, team, and departmental goals and incentives. Finally, these banks promoted teamwork, especially the sharing of strategic knowledge throughout the organization.

Strategic readiness is related to the concept of liquidity, which accountants use to classify financial and physical assets on a company's balance sheet. Accountants divide a firm's assets into various categories, such as cash, accounts receivable, inventory, property, plant and equipment, and long-term investments. These are ordered hierarchically according to the ease and speed with which they can be converted to cash-in other words, according to the degree of their liquidity. Accounts receivable is more liquid than inventory, and both accounts receivable and inventory are classified as short-term assets since they typically convert to cash within 12 months, faster than the cash recovery cycle 
from such illiquid assets as plant and equipment. Strategic readiness does much the same for intangible assets-the higher their state of readiness, the faster they contribute to generating cash.

\section{Human Capital Readiness}

All jobs are important to the organization; otherwise, people wouldn't be hired and paid to perform them. Organizations may require truck drivers, computer operators, production supervisors, materials handlers, and call center operators and should make it clear that contributions from all these employees can improve organizational performance. But we have found that some jobs have a much greater impact on strategy than others. Managers must identify and focus on the critical few that have the greatest impact on successful strategy implementation.

Once a company identifies its strategic job families, it must define the requirements for these jobs in considerable detail, a task often referred to as "job profiling" or "competency profiling." A competency profile describes the knowledge, skills, and values required by successful occupants in the job family. Often, HR managers will interview individuals who best understand the job requirements to develop a competency profile they can use to recruit, hire, train, and develop people for that position. To see how this might be done, consider Consumer Bank, a composite example distilled from a dozen retail banks.

Consumer Bank was migrating from its historic strategy of promoting individual products to one offering complete financial solutions and one-stop shopping to targeted customers. The map for this new strategy identified seven critical internal processes, one of which was "cross-sell the product line." Human resources and line executives then identified the financial planner as the job most important to the effective performance of this process. A planning workshop further identified four skills fundamental to the financial planner's job: solutions selling, relationship management, product-line knowledge, and professional certification. For each internal process on its strategy map, Consumer Bank replicated this approach, identifying the strategic job families and critical competencies each required.

To take the next step-assessing the current capabilities and competencies of each of the employees in each strategic job family- 
companies can draw from a broad range of approaches. For example, employees can themselves assess how well their current capabilities fit the job requirements and then discuss those assessments with a mentor or career manager. Alternatively, an assessor can solicit 360-degree feedback on employees' performance from their supervisors, peers, and subordinates. From these assessments, employees get a clear understanding of their objectives, meaningful feedback on their current levels of skill and performance, and specific recommendations for future personal development.

Consumer Bank estimated that it needed 100 trained and skilled financial planners to execute the cross-selling process. But in assessing its recent targeted hiring, training, and development programs, the bank's HR group determined that only 40 of its financial planners had reached a high enough level of proficiency. The bank's human capital readiness for this piece of the strategy was, therefore, only $40 \%$. By replicating this analysis for all its strategic job families, the bank learned the state of its human capital readiness and thus whether the organization could move forward quickly with its new strategy.

\section{Information Capital Readiness}

Executives must understand how to plan, set priorities for, and manage an information capital portfolio that supports their organization's strategy. As with human capital, the strategy map serves as a starting point for delineating a company's objectives. In the case of Consumer Bank, the chief information officer led an initiative to identify the specific information capital needs of each of the seven internal processes previously identified as critical to the bank's new value proposition.

\section{Organization Capital Readiness}

Success in performing the critical internal processes identified in an organization's strategy map invariably requires an organization to change in fundamental ways. Assessing $O C$ readiness is essentially about assessing how well the company can mobilize and sustain the organization change agenda associated with its strategy. For instance, if the strategy involves focusing on the customer, the company needs to determine whether its existing culture is customer-centric, whether its leaders have 
the requisite skills to foster such a culture, whether employees are aware of the goal and are motivated to deliver exceptional customer service, and, finally, how well employees share with others their knowledge about the company's customers. Let's explore how companies can make these kinds of assessments for each of the four OC dimensions.

Culture. Of the four, culture is perhaps the most complex and difficult dimension to understand and describe because it encompasses a wider range of behavioural territory than the others. Executives generally believe that changes in strategy require basic changes in the way business is conducted at all levels of the organization, which means, of course, that people will need to develop new attitudes and behaviours-in other words, change their culture.

Assessment of cultural readiness relies heavily on employee surveys. But in preparing surveys, companies need to distinguish clearly between the values that all employees share-the company's base culture-and the perceptions that employees have of their existing system-the climate. The concept of base culture has its roots in anthropology, which defines an organization's culture as the symbols, myths, and rituals embedded in the group consciousness (or subconscious). To describe a company's base culture, therefore, you have to uncover the organization's systems of shared meanings, assumptions, and values.

The concept of climate has its roots in social psychology and is determined by the way organizational influences-such as the incentive structure or the perceived warmth and support of superiors and peers-affect employees' motivation and behaviour. The anthropological component reflects employees' shared attitudes and beliefs independent of the actual organizational infrastructure, while climate reflects their shared perception of existing organizational policies, practices, and procedures, both formal and informal.

Leadership. If companies change their strategies, people will have to do some things differently as well. It is the responsibility of leaders at all levels of the organization-from the CEO of a retail chain down to the local store managers-to help employees identify and understand the changes needed and to motivate and guide them toward the new ways of working.

In researching the best practices it is possible to identify seven generic types of behavioural changes that build organization capital, and each fell into one of two categories: changes that support 
the creation of value-such as increasing people's focus on the customerand those required to carry out the company's strategy-such as increasing accountability.

\section{BIBLIOGRAPHY}

KAPLAN, Robert S.; NORTON, David P. (1996) The Balanced Scorecard. Boston, Massachusetts: Harvard Business Press.

LAWRENCE, Paul R. et al. (1990) Behind the factory walls. Boston, Massachusetts: Harvard Business Press.

MCKINNON, Ronald (1973) Money and Capital in Economic Development. Washington, D.C.: Brookings Institution. 
Russian Financial Sector: Adjustment and Management 